\title{
Diversity of Insect Pollinators Associated with Pigeonpea, Cajanus cajan L. Mill sp. And Their Impact on Crop Production
}

\author{
Ichpal Singh, Uma Shankar* , D.P. Abrol and Amit Mondal
}
Division of Entomology, Faculty of Agriculture, Sher-e-Kashmir University of Agricultural Sciences and Technology, Faculty of Agriculture, Chatha Jammu 180002 (J\&K), India *Corresponding author

\section{A B S T R A C T}

\begin{tabular}{|c|}
\hline Keywords \\
\hline $\begin{array}{l}\text { Cajanus cajan, } \\
\text { Pollinators, } \\
\text { Honeybees, } \\
\text { Solitary bees, } \\
\text { Crop production. }\end{array}$ \\
\hline Article Info \\
\hline $\begin{array}{l}\text { Accepted: } \\
\text { 04 July } 2017 \\
\text { Available Online: } \\
\text { 10 September } 2017\end{array}$ \\
\hline
\end{tabular}

\section{Keywords}

Cajanus cajan,

Pollinators,

Honeybees,

Solitary bees,

Article Info

Accepted:

Available Online:

10 September 2017
The studies were conducted to determine the impact of pollinators on the production of Pigeonpea, Cajanus cajan L. during 2013-14 and 2014-15. Studies on pollinator complex revealed that $C$. cajan flowers attracted 15 species of insects belonging to five families, 7 genera and three orders. The insect belongs to order Hymenoptera were most abundant. Of all the bees, megachilid bees were most abundant and compared more than $50 \%$ of the total flower visiting insects followed by honeybees $39.4 \%$ and anthophorid bees $6.6 \%$. The insects belonging to order Lepidoptera and Diptera which were reported in very small numbers at interrupted hours. The studies revealed that bee pollination was superior to all other treatments in improving qualitative and quantitative parameters of $C$. cajan crops in the order: bee pollination $>$ open pollination $>$ hand pollination $>$ selfpollination > Carbaryl 50 WP $0.1 \%$ + Open pollination > Imidacloprid 17.8 SL $0.05 \%+$ Open pollination.

\section{Introduction}

In India, more than 80 per cent people depend upon vegetarian food wherein, pulses constitute a major component of their diet. Pulses occupy an important place in human nutrition, especially among the low-income groups of people in developing countries and constitute the world's third largest group of plant life which belongs to the Fabaceae or Leguminosae family. They have miraculous properties like high nutritional value and low water requirements, ability to self-fertilize, improving soil and crops health by fixing nitrogen contents and above all maintaining the health benefits to the people (Kannaiyan,
1999; Sharma et al., 2006). They are the major sources of dietary protein (Osorio-Diaz et al., 2003), essential amino acids and are vital for sustainability of our crop production systems (Tharanathan and Mahadevamma 2003), soil health and above all for our food security. Tremendous progresses have been achieved through the technological interventions in food grain production but such a progress is yet to be achieved in production of pulses. Keeping in view the importance of pulses very recently, FAO has celebrated (2015) as the International Year of Pulses to raise the pulse production to impart 
the food and malnutrition security for the masses.

Among the pulses, Pigeonpea (Cajanus cajan L. Millsp.) is the second most important and highly profitable pulse crop grown under wide variety of agroclimatic conditions and under varied cropping systems in different states in the country. It is a multipurpose legume consumed in various parts of the world and is grown in 4.42 million ha with an annual production of 2.89 million tonnes and $655 \mathrm{~kg} \mathrm{ha}^{-1}$ of productivity in India. It requires a tropical climate for its growth and development. Pigeonpea crop is benefitted by pollinators which enhance their yield both quantitatively and qualitatively. All pulse crops are open pollinated to varying degrees, which means in order to achieve seed set pollen must be transferred between flowers. Although flowers are often cross pollinated, natural cross-pollination ranging from 0.1 $48.0 \%$ has been reported by various workers (Howard et al., 1919). Benefit has been reported up to $1,100 \%$ in bean and $600 \%$ in kidney beans. Like soybean, Pigeonpea and other pulses is self-pollinated crop but yield increases by bee pollination have been observed (Abrol and Shankar, 2015). Singh (2016) indicated that Megachile spp., Xylocopa tenuiscopa, Amegilla zonata and Nomia sp. were true pollinators and out of these, Megachile spp. was key pollinators of Pigeonpea. India's high level of pulse demand is set to continue as a result of increased population growth and rising disposable income. In view of the above, studies were conducted to determine the diversity of insect pollinators associated with these crops and their impact on crop production.

\section{Materials and Methods}

\section{Location and site of the experiment}

The studies on pollinators of Pigeonpea, $C$. cajan were carried out at four locations i.e., at farmer's field at Samba, Kathua, Marh and University campus Chatha Jammu, during Khraif season 2013 and 2014 (300m above sea level). Samba is situated $40 \mathrm{~km}$, Kathua $80 \mathrm{~km}$ and Marh $30 \mathrm{~km}$ away from Main Campus Chatha, respectively. In case of Pigeonpea, variety PAU-881 was used. The crop was sown between $10-15^{\text {th }}$ July each year in a randomized block design. Cultural operations were done according to the revised package of practices for agricultural crops (kharif) of SKUAST-J (2012).

Collection and identification of true pollinators and other pollinators

Number of insect pollinators of each species visiting fields was recorded at 10 per cent flowering till its complete cessation. Observations was made for different groups of pollinators visiting the field during flowering at regular interval of time for five minutes in each square meter area from five spot during peak flowering period. The rate of flower visitation and number of nectar and pollen collectors was also recorded. Sweep net method (measuring $40 \mathrm{~cm}$ in diameter) was used to collect insects flying over the plots and eye observation were used to clear and settle insects. Insects were identified to the level of species, when possible, using published systematic keys. Simultaneously meteorological parameters were also recorded to correlate with pollinators.

\section{Impact of insect pollination on Pigeonpea crop production}

For assessing the impact of insect pollination on crop production, experiment was divided into six treatments given below-

Quantitative parameters include pod weight, number of seeds per pod, weight of 1000 seeds and seed yield per plant whereas, qualitative parameters comprise germination $(\%)$, seedling vigour and oil content (\%). 


\section{Estimation of protein}

The protein content of foods is mostly been determined on the basis of total nitrogen content. The Kjeldahl method is almost universally applied to determine nitrogen content, total nitrogen is then multiplied by a factor to arrive at the protein content. Protein concentration in the extracts was determined by the method of Micro Kjeldahl (1996). The data on quantitative and qualitative parameters were statistically analyzed using ANOVA (SAS Institute 2002). When F-test was significant, means were separated using Tukey's Honestly Significant Difference (HSD) Test at the 0.05 level of significance.

\section{Results and Discussion}

\section{Insect pollinators visiting pigeonpea}

The studies were conducted on pollinator complex visiting Pigeonpea at three different location of Jammu division which included Marh, Kathua, Samba and Chatha. The study revealed that Apis millifera, Apis dorsata and Megachile lanata were recorded at all the locations during two consecutive years. The field visit of Apis cerana was recorded at all the locations during 2013-2014 while as it was recorded only from three locations which included Kathua, Samba and Chatha during 2014-2015.

The foraging activity of Apis florea was recorded only at Kathua and Chatha during 2013-2014 and only at Chatha during 20142015 (Table 1). The field activity of Xylocopa latipes was recorded at Kathua, Samba and Chatha during 2013-2014, while its foraging activity was recorded from all the four locations during 2014-2015. The foraging activity of $X$. pubescens was recorded from Kathua and Chatha locations during 20132014 and Kathua, Samba and Chatha during 2014-2015. The field activity of Amegilla zonata was recorded at Kathua, Samba and
Chatha during 2013-2014 While during 20142015 it was recorded from Kathua and Chatha only. The M. bicolor was recorded from Samba and Chatha while as, M. caphalotes and M. disjuncta were recorded from Kathua, Samba and Chatha during 2013-2014. During 2014-2015, M. bicolor was recorded from Marh, Kathua and Chatha only. While as, $M$. caphalotes was recorded from all the four locations of study and $M$. disjuncta from Kathua and Chatha only. Other insect visitor of Pigeonpea included housefly and adult butterflies. The field activity of housefly and adult butterfly were recorded at all the four locations during 2013-2014 and 2014-2015.

\section{Pollinator complex on pigeonpea}

The result revealed that pollinator species from order Hymenoptera, Lepidoptera and Diptera were found visiting the field during peak flowering at regular interval of time. In the order Hymenoptera, the field visit by the family Megachilidae was 50\% followed by family Apidae 46\%. In the order Lepidoptera and Diptera, the field visit by pollinator spices Danaus plexippus, Pieris rapae and Musca spp was $1.60 \%, 1.20 \%$ and $1.20 \%$, respectively.

\section{Abundance and diversity of pollinators on pigeonpea}

The data presented in Table 2 revealed that Pigeonpea flowers attracted 15 species of insects belonging to five families, 7 genera and three orders. The insect belongs to order Hymenoptera were most abundant and compared to honeybees Apis dorsata, A. mellifera, A. cerana, A. florea, solitary bees, Xylocopa latipes, X. pubescence, Amegill azonata, Megachile bicolor, M. lanata, M. hera, M. cephalotes and M. disjuncta. Of all the bees, megachile bees were most abundant and compared more than $50 \%$ of the total flower visiting insects followed by honeybees $39.4 \%$ and anthophorid bees $6.6 \%$. The 
insects belonging to order Lepidoptera and Diptera consisting of moths and butterflies such as Macroglossum stellatarum, Pieris rapae and house flies which were reported in very small number.

\section{Impact of pollinator on quantitative and qualitative parameter of pigeonpea}

Result showed significant difference in all quantitative parameters including pod weight; number of seeds/pod; weight of 1000 seeds; seed yield per plant. Pod weight of Pigeonpea crop in bee pollination treatment $\left(\mathrm{T}_{4}\right)$ showed higher valves than rest of the other treatment in season $2013(\mathrm{~F}=6.227 ; \mathrm{P} \leq 0.005)$ and in 2014 ( $\mathrm{F}=5.999 ; \mathrm{P} \leq 0.005)$, the lower values for pod weight was observed in case of selfpollination $\left(\mathrm{T}_{2}\right)$. Number of seed per pod showed high values in bee pollination $\left(\mathrm{T}_{4}\right)$ followed by open pollination $\left(\mathrm{T}_{3}\right)$ in 2013 $(\mathrm{F}=8.252 ; \mathrm{P} \leq 0.001)$ and in $2014(\mathrm{~F}=15.024$; $\mathrm{P} \leq 0.000)$, less values for number of seed per plants is observed in self-pollination (T2). The thousand seed weight was also high in bee pollination treatment $\left(\mathrm{T}_{4}\right)$ followed by open pollination treatment $\left(\mathrm{T}_{3}\right)$ in $2013(\mathrm{~F}=$ 4.585; $\mathrm{P} \leq 0.000)$ and in $2014(\mathrm{~F}=10.087 ; \mathrm{P} \leq$ 0.000), less values in self-pollination treatment $\left(\mathrm{T}_{2}\right)$. Seed yield per plant was high in bee pollination treatment $\left(\mathrm{T}_{4}\right)$ followed by open pollination treatment $\left(\mathrm{T}_{3}\right)$ in $2013(\mathrm{~F}=$ 26.932; $\mathrm{P} \leq 0.000)$ and in $2014(\mathrm{~F}=27.692 ; \mathrm{P} \leq$ $0.000)$, less values in self-pollination treatment $\left(\mathrm{T}_{2}\right)$. Therefore, the data from Table 3 showed that the bee pollination treatment
(T4) has high values for each quantitative parameter in season 2013 and 2014.

Qualitative parameters including germination percentage, seed vigor and protein content percentage were measured in $C$. cajan during season 2013 and 2014 in all the six different treatments showed that germination percentage recorded high value in bee pollination treatment (T4) followed by open pollination (T3) in $2013(\mathrm{~F}=6.730 ; \mathrm{P} \leq 0.000)$ and in $2014(\mathrm{~F}=6.243 ; \mathrm{P} \leq 0.002)$, low value in self-pollination treatment (T2). Seed vigor (shoot and root length) recorded high values in bee pollination followed by open pollination in $2013(\mathrm{~F}=82.985 ; \mathrm{P} \leq 0.000$ and $\mathrm{F}=23.704 ; \mathrm{P} \leq 0.000)$ and in $2014(\mathrm{~F}=57.49$; $\mathrm{P} \leq 0.000$ and $\mathrm{F}=54.71 ; \mathrm{P} \leq 0.000$ ), low value in self-pollination. Also protein content recorded the high value in bee pollination treatment followed by open pollination treatment in $2013(\mathrm{~F}=50.673 ; \mathrm{P} \leq 0.000)$ and in $2014(\mathrm{~F}=4.495 ; \mathrm{P} \leq 0.000)$, low value recorded in self-pollination. Results revealed that the bee pollination treatment (T4) had significant effect on the qualitative parameters with germination percentage of $64.80 \%$.

Shoot length $2.77 \mathrm{~cm}$ and root length $2.52 \mathrm{~cm}$ and protein content recorded is $2.06 \mathrm{mg} / \mathrm{ml}$ in 2013. Similarly, in 2014 the bee pollination treatment (T4) also showed significant effect on the qualitative parameters with germination percentage of $67.71 \%$. Shoot length $2.84 \mathrm{~cm}$ and root length $2.65 \mathrm{~cm}$ and protein content recorded is $2.24 \mathrm{mg} / \mathrm{ml}$.

\section{Impact of insect pollination on pigeonpea crop production}

\begin{tabular}{|l|l|}
\hline 1 & Hand pollination: Emasculation of anthers and hand pollination \\
\hline 2 & $\begin{array}{l}\text { Self-pollination: For this purpose counted numbers of plants were enclosed in } \\
\text { pollination cages }(5 \times 3 \text { meters }) / \text { bags. }\end{array}$ \\
\hline 3 & Open pollination: Counted numbers of plants were left for open pollination \\
\hline 4 & Bee pollination: Crop caged with bees \\
\hline 5 & Carbaryl 50 WP 0.1\%+ Open pollination \\
\hline 6 & Imidacloprid 17.8 SL $0.05 \%+$ Open pollination \\
\hline
\end{tabular}


Table.1 List of insect pollinators visiting pigeonpea, C. cajan

\begin{tabular}{|c|c|c|c|c|c|c|c|c|c|}
\hline \multirow[t]{2}{*}{ Insect visitors } & \multirow[t]{2}{*}{ Family: Order } & \multicolumn{4}{|c|}{ 2013-2014 } & \multicolumn{4}{|c|}{ 2014-2015 } \\
\hline & & Marh & Kathua & Samba & Chatta & Marh & Kathua & Samba & Chatta \\
\hline Apis mellifera & \multirow{7}{*}{ Apidae: Hymenoptera } & $\checkmark$ & $\checkmark$ & $\checkmark$ & $\checkmark$ & $\checkmark$ & $\checkmark$ & $\checkmark$ & $\checkmark$ \\
\hline Apis dorsata & & $\checkmark$ & $\checkmark$ & $\checkmark$ & $\checkmark$ & $\checkmark$ & $\checkmark$ & $\checkmark$ & $\checkmark$ \\
\hline Apis cerana & & $\checkmark$ & $\checkmark$ & $\checkmark$ & $\checkmark$ & $\mathrm{x}$ & $\checkmark$ & $\checkmark$ & $\checkmark$ \\
\hline Apis florea & & $\mathrm{x}$ & $\checkmark$ & $\mathrm{x}$ & $\checkmark$ & $\mathrm{x}$ & $\mathrm{x}$ & $\mathrm{x}$ & $\checkmark$ \\
\hline Xylocopalatipes & & $\mathrm{x}$ & $\checkmark$ & $\checkmark$ & $\checkmark$ & $\checkmark$ & $\checkmark$ & $\checkmark$ & $\checkmark$ \\
\hline Xylocopapubecens & & $\mathrm{x}$ & $\checkmark$ & $\mathrm{x}$ & $\checkmark$ & $\mathrm{x}$ & $\checkmark$ & $\checkmark$ & $\checkmark$ \\
\hline Amgellia zonata & & $\mathrm{x}$ & $\checkmark$ & $\checkmark$ & $\checkmark$ & $\mathrm{x}$ & $\checkmark$ & $\mathrm{x}$ & $\checkmark$ \\
\hline Megachile. lanata & \multirow{4}{*}{$\begin{array}{l}\text { Megachilidae: } \\
\text { Hymenoptera }\end{array}$} & $\checkmark$ & $\checkmark$ & $\checkmark$ & $\checkmark$ & $\checkmark$ & $\checkmark$ & $\checkmark$ & $\checkmark$ \\
\hline Megachile bicolor & & $\mathrm{x}$ & $\mathrm{x}$ & $\checkmark$ & $\checkmark$ & $\checkmark$ & $\checkmark$ & $\mathrm{x}$ & $\checkmark$ \\
\hline Megachilecephalotes & & $\mathrm{x}$ & $\checkmark$ & $\checkmark$ & $\checkmark$ & $\checkmark$ & $\checkmark$ & $\checkmark$ & $\checkmark$ \\
\hline Megachiledisjuncta & & $\mathrm{x}$ & $\checkmark$ & $\checkmark$ & $\checkmark$ & $\mathrm{x}$ & $\checkmark$ & $\mathrm{x}$ & $\checkmark$ \\
\hline House Fly & Muscidae: Diptera & $\checkmark$ & $\checkmark$ & $\checkmark$ & $\checkmark$ & $\checkmark$ & $\checkmark$ & $\checkmark$ & $\checkmark$ \\
\hline Adult Butterfly & Pieridae: Lepidoptera & $\checkmark$ & $\checkmark$ & $\checkmark$ & $\checkmark$ & $\checkmark$ & $\checkmark$ & $\checkmark$ & $\checkmark$ \\
\hline
\end{tabular}


Table.2 Insect pollinator complex recorded on Pigeonpea, C. cajan bloom during 2013-14

\begin{tabular}{|c|c|c|c|c|}
\hline Order & Family & Species & Percentage proportion & Total \\
\hline \multirow[t]{2}{*}{ Hymenoptera } & Apidae & $\begin{array}{l}\text { Apismellifera } \\
\text { A. dorsata } \\
\text { A. cerana } \\
\text { A. florea } \\
\text { Xylocopalatipes } \\
\text { X.pubecens } \\
\text { Amegillazonata } \\
\end{array}$ & $\begin{array}{l}20.80 \\
6.50 \\
9.40 \\
2.70 \\
2.30 \\
2.80 \\
1.50 \\
\end{array}$ & 46 \\
\hline & Megachilidae & $\begin{array}{l}\text { Megachilelanata } \\
\text { M. bicolor } \\
\text { M. hera } \\
\text { M. cephalotes } \\
\text { M. disjuncta } \\
\end{array}$ & $\begin{array}{l}12.75 \\
22.12 \\
5.07 \\
6.93 \\
3.13 \\
\end{array}$ & 50 \\
\hline \multirow[t]{2}{*}{ Lepidoptera } & Hawk moth & Macroglossumstellatarum & 1.60 & 1.60 \\
\hline & Pieridae & Pierisrapae & 1.20 & 1.20 \\
\hline Diptera & Muscidae & Musca spp. & 1.20 & 1.20 \\
\hline
\end{tabular}

Table.3 Impact of insect pollinators on quantitative and qualitative parameters of Cajanus cajan

\begin{tabular}{|c|c|c|c|c|c|c|c|c|c|c|c|c|c|c|c|c|}
\hline \multirow[t]{3}{*}{ Treatment } & \multirow{2}{*}{\multicolumn{2}{|c|}{ Pod weight (g) }} & \multirow{2}{*}{\multicolumn{2}{|c|}{$\begin{array}{l}\text { Number of } \\
\text { seeds/pod }\end{array}$}} & \multirow{2}{*}{\multicolumn{2}{|c|}{$\begin{array}{l}\text { Weight of } 1000 \\
\text { seeds }(\mathrm{g})\end{array}$}} & \multirow{2}{*}{\multicolumn{2}{|c|}{\begin{tabular}{|l} 
Seed yield \\
(g)/plant
\end{tabular}}} & \multirow{2}{*}{\multicolumn{2}{|c|}{ Germination (\%) }} & \multicolumn{4}{|c|}{\begin{tabular}{|l|} 
Seedlings vigour \\
\end{tabular}} & \multirow{2}{*}{\multicolumn{2}{|c|}{$\begin{array}{l}\text { Protein content } \\
(\mathrm{mg} / \mathrm{ml})\end{array}$}} \\
\hline & & & & & & & & & & & \multicolumn{2}{|c|}{\begin{tabular}{|l|} 
Shoot length \\
(cms)
\end{tabular}} & \multicolumn{2}{|c|}{ Root length (cms) } & & \\
\hline & 2013 & 2014 & 2013 & 2014 & 2013 & 2014 & 2013 & 2014 & 2013 & 2014 & 2013 & 2014 & 2013 & 2014 & 2013 & 2014 \\
\hline Hand pollination & $0.41^{\mathrm{abc}}$ & $047^{\mathrm{b}}$ & $1.74^{\mathrm{ab}}$ & $1.82^{\mathrm{abc}}$ & $8.60^{\mathrm{abc}}$ & $8.78^{\mathrm{ab}}$ & $0.59^{\mathrm{c}}$ & $0.67^{\mathrm{c}}$ & $58.71^{\mathrm{ab}}$ & $61.91^{\mathrm{abc}}$ & $2.61^{\mathrm{c}}$ & $2.71^{\mathrm{b}}$ & $2.33^{\mathrm{c}}$ & $2.45^{\mathrm{c}}$ & $1.86^{\mathrm{c}}$ & $1.96^{\mathrm{ab}}$ \\
\hline Self-pollination & $0.27^{\mathrm{a}}$ & $0.32^{\mathrm{a}}$ & $1.61^{\mathrm{a}}$ & $1.68^{\mathrm{a}}$ & $8.29^{\mathrm{a}}$ & $8.39^{\mathrm{a}}$ & $0.32^{\mathrm{a}}$ & $0.46^{\mathrm{a}}$ & $53.75^{\mathrm{a}}$ & $56.21^{\mathrm{a}}$ & $2.37^{\mathrm{a}}$ & $2.45^{\mathrm{a}}$ & $2.11^{\mathrm{a}}$ & $2.22^{\mathrm{a}}$ & $1.69^{\mathrm{a}}$ & $1.74^{\mathrm{a}}$ \\
\hline Open pollination & $0.46^{\mathrm{bc}}$ & $0.51^{\mathrm{bc}}$ & $1.76^{\mathrm{ab}}$ & $1.88^{\mathrm{bc}}$ & $8.89^{\mathrm{bc}}$ & $9.11^{\mathrm{bc}}$ & $0.65^{\mathrm{c}}$ & $0.73^{\mathrm{c}}$ & $61.52^{\mathrm{bc}}$ & $64.56^{\mathrm{bc}}$ & $2.66^{\mathrm{c}}$ & $2.81^{\mathrm{bc}}$ & $2.41^{\text {cd }}$ & $2.59^{\mathrm{bc}}$ & $1.94^{\mathrm{c}}$ & $2.10^{\mathrm{ab}}$ \\
\hline Bee pollination & $0.54^{\mathrm{c}}$ & $0.60^{\mathrm{c}}$ & $1.84^{\mathrm{c}}$ & $1.96^{\mathrm{c}}$ & $9.00^{\mathrm{c}}$ & $9.19^{\mathrm{c}}$ & $0.81^{\mathrm{d}}$ & $0.91^{\mathrm{d}}$ & $64.80^{c}$ & $67.71^{\mathrm{c}}$ & $2.77^{\mathrm{d}}$ & $2.84^{\mathrm{c}}$ & $2.52^{\mathrm{d}}$ & $2.65^{\mathrm{d}}$ & $2.06^{\mathrm{d}}$ & $2.24^{\mathrm{c}}$ \\
\hline $\begin{array}{l}\text { Carbaryl } 50 \mathrm{WP} \\
0.1 \%+\text { Open } \\
\text { pollination }\end{array}$ & $0.39^{\mathrm{abc}}$ & $0.44^{\mathrm{b}}$ & $1.69^{\mathrm{ab}}$ & $1.77^{\mathrm{ab}}$ & $8.53^{\mathrm{abc}}$ & $8.65^{\mathrm{a}}$ & $0.52^{\mathrm{bc}}$ & $0.62^{\mathrm{bc}}$ & $57.51^{\mathrm{ab}}$ & $61.40^{\mathrm{abc}}$ & $2.51^{\mathrm{b}}$ & $2.65^{\mathrm{b}}$ & $2.28^{\mathrm{bc}}$ & $2.39^{\mathrm{bc}}$ & $1.79^{\mathrm{bc}}$ & $1.84^{\mathrm{ab}}$ \\
\hline $\begin{array}{l}\text { Imidacloprid } 17.8 \\
\text { SL } 0.05 \%+\text { Open } \\
\text { pollination }\end{array}$ & $0.36^{\mathrm{ab}}$ & $0.40^{\mathrm{ab}}$ & $1.64^{\mathrm{a}}$ & $1.72^{\mathrm{a}}$ & $8.38^{\mathrm{ab}}$ & $8.51^{\mathrm{a}}$ & $0.41^{\mathrm{ab}}$ & $0.52^{\mathrm{ab}}$ & $56.94^{\mathrm{ab}}$ & $58.23^{\mathrm{ab}}$ & $2.43^{a}$ & $2.49^{\mathrm{a}}$ & $2.19^{\mathrm{ab}}$ & $2.30^{\mathrm{ab}}$ & $1.73^{\mathrm{ab}}$ & $1.89^{\mathrm{ab}}$ \\
\hline $\begin{array}{l}\mathrm{F} / P \\
(\mathrm{df}=5,12)\end{array}$ & $\begin{array}{l}6.227 / 0 . \\
005\end{array}$ & $\begin{array}{l}5.999 / 0 \\
.005\end{array}$ & $\begin{array}{l}8.252 / 0 . \\
001\end{array}$ & $\begin{array}{l}15.024 / \\
0.000\end{array}$ & $\begin{array}{l}4.585 / 0.0 \\
08\end{array}$ & $\begin{array}{l}10.087 \\
/ 0.000\end{array}$ & $\begin{array}{l}26.932 / 0 . \\
000\end{array}$ & \begin{tabular}{|l|}
$27.692 /$ \\
0.000
\end{tabular} & $\begin{array}{l}6.730 / 0.00 \\
1\end{array}$ & $\begin{array}{l}6.243 / 0.0 \\
02\end{array}$ & \begin{tabular}{|l|}
$82.985 /$ \\
0.00
\end{tabular} & \begin{tabular}{|l|}
$57.491 /$ \\
0.000
\end{tabular} & $\begin{array}{l}23.704 / 0.0 \\
0\end{array}$ & $\begin{array}{l}54.717 / 0.0 \\
00\end{array}$ & $\begin{array}{l}50.673 / 0 . \\
00\end{array}$ & $4.495 / 0.015$ \\
\hline
\end{tabular}

Mean \pm SE followed by the same letter within a column are not statistically different (Tukey's HSD test; $\mathrm{P}<0.05$ ) 
The findings on insect pollinators visiting Pigeonpea in the present study are in agreement with the findings of Singh (2016) who reported that 7 insect species were true pollinators where Megachile spp., $X$. tenuiscapa, A. zonata and Nomia sp. are the major pollinators of pigeonpea. Similarly, Chaudhary and Jain (1978) reported that Megachile lamata was the important pollinator of Pigeonpea throughout India, Srilanka and Burma. Williams (1977) reported that honey bees were the major pollinators and other bees do pollinate in Pigeonpea (Cajanus cajanus. L). Similar observations were also made by Brar et al., (1992), in Pigeonpea. Some variations in the present study and earlier studies on insect pollinators visiting Pigeonpea and other pulse crops may be due to inherent character such as colour of the flowers, presence of nectar guides on the flowers, availability of forage source, in addition to soil and climatic condition of the experimental site.

The present findings on qualitative and quantitative parameters of Pigeonpea are in conformity with the findings of Rathi and Sihag (1993) in Pigeonpea. They recorded that the maximum pod set, pod length, pod volume, 100- pod weight, number of seeds per pod, seed size, seed weight and germination per cent was recorded in open pollination, followed by $A$. florea, A. cerana and $T$. iridipennis pollination plot $(96.56 \%$, $5.94 \mathrm{~cm}, 10.40 \mathrm{ml}, 83.01 \mathrm{~g}, 4.80,0.056 \mathrm{~mm}$, $85.10 \mathrm{~g}$ and $83.64 \%$ respectively, $91.62 \%$, $5.72 \mathrm{~cm}, 9.10 \mathrm{ml}, 75.27 \mathrm{~g}, 4.40,0.046,80.61$ $\mathrm{g}$ and $79.80 \%$ respectively, $85.40 \%, 5.66 \mathrm{~cm}$, $7.20 \mathrm{ml}, 65.13 \mathrm{~g}, 4.20,0.043,76.51 \mathrm{~g}$ and $75.95 \%$, respectively and $82.59 \%, 5.41 \mathrm{~cm}$, $6.30 \mathrm{ml}, 53.25 \mathrm{~g}, 3.80,0.040 \mathrm{~mm}, 71.51 \mathrm{~g}$ and $71.71 \%$, respectively). The maximum seed vigour (1227) was recorded in A. florea, followed by open pollination (1088) and $A$. cerana (785) and minimum seed vigour of 565 was recorded in $T$. iridipennis pollination plot. In a similar study, Pando et al., (2011) reported that Pigeonpea (Cajanus cajan) shows pollination deficit even under normal circumstances, considering that flowers visited by Chalicodoma cincta cincta had higher yields compared with those under unlimited access by all visitors. The fruiting rate, the number of seeds/ pod and the percentage of normal seeds of unprotected inflorescences were significantly higher than those of inflorescences protected from insects. C. c. cincta foraging resulted to a significant increment of the fruiting rate by $19.65 \%$, as well as the number of seeds/per pod by 24.33 $\%$ and the percentage of normal seeds by $11.52 \%$. Conservation of $C$. c. cincta nests close to $C$. cajan fields could be recommended to improve pod and seeds production.

Pigeonpea crops are visited by a large number of pollinators which can be helpful in boosting the crop production. The provision of floral resources within the crop for supporting beneficial insect pollinator populations could be a promising strategy to enhance environmental function of pulses by manipulating the foraging places and nesting sites of different types of bees for sustainable agriculture.

\section{References}

Abrol, D. P., and Shankar, U. 2015. Role of Pollination in Pulses. Advances in Pollen Spore Research, 33: 101-103.

Brar, H. S., Jhaji, H. S. and Gatoria, G. S. 1992. Abundance and activity of the bee visitors of Pigeonpea (Cajanus cajan (L.) Mill sp.) And role of Apis mellifera L. in its pollination. Indian Bee Journal, 54 (1-4): 76-80.

Chaudhary, J. P., and Jain, J. L. 1978. Nesting and foraging behaviour of a mason bee Megachile lanata Lepel (Megachilidae: Hymenoptera). Indian Journal of 
Entomology, 40:405-411.

Howard, A., Howard, G. L. C. and Khan, L. N. 1919. Studies in the pollination of Indian Crops. Memoirs of the Department of Agriculture in India (Botanical Senes) 10: 201-207.

Osorio-Diaz, P., Bello-Perez, L. A., SayagoAyerdi, S. G., Del Pilar Benitez-Reyes, M., Tovar, J. and Paredes-Lopez, O. 2003. Effect of processing and storage time on in vitro digestibility and resistant starch content of two bean (Phaseolus vulgaris) varieties. J. Sci Food Agric., 83: 1283-88.

Pando, J. B., Fohouo, F. N. T. and Tamesse, J. L. 2011. Pollination and yield responses of Pigeonpea (Cajanus cajan L. Mill sp.) to the foraging activity of Chalicodoma cincta cincta (Hymenoptera: Megachilidae) in Yaoundé (Cameroon). Journal of Animal \& Plant Sciences, 11(1): 13461357.

Rathi, A., and Sihag, R. C. 1993. Differential attractiveness of Brassica campestris L and Cajanus cajan L (Millsp) to two honey bee species. In: Proceedings of an international symposium on pollination in tropics, Bangalore (pp. 113-119).

Sharma, P., Sekhon, H. S. and Singh, G. 2006. Biological nitrogen fixation in mung bean: An overview. In: Proceedings of the Final Workshop and Planning Meeting. Improving Income and Nutrition By Incorporating Mung Bean in Cereal Fallows in the IndoGangetic Plains of South Asia (Shanmugasundaram S, ed.). DFID Mung Bean Project for 2002-2004, May 27-31. Ludhiana, Punjab, India. p 189-203.

Singh, A. K., 2016. Pollinating Efficiency of Native Bee Pollinators of Pigeonpea (Cajanus cajan) in Nagaland. Russian Journal of Ecology, 47(3): 310-314.

Tharanathan, R. N., and Mahadevamma, S. 2003. Grain legumes- a boon to human nutrition. Trends Food Sci Technol., 14: 507-18.

Williams, I. H., 1977. Behaviour of insects foraging on Pigeonpea (Cajanus cajan L. Millsp.) in India. Tropical Agriculture, 54: 353-363.

\section{How to cite this article:}

Ichpal Singh, Uma Shankar, D.P. Abrol and Amit Mondal. 2017. Diversity of Insect Pollinators Associated with Pigeonpea, Cajanus cajan L. Mill sp. and Their Impact on Crop Production. Int.J.Curr.Microbiol.App.Sci. 6(9): 528-535. doi: https://doi.org/10.20546/ijcmas.2017.609.063 